\title{
Gradient (elevation) vs. disturbance (agriculture) effects on primary cloud forest in Ecuador: floristics and physical structure
}

Randall W. Myster

\begin{abstract}
Background: Cloud forests are common in the Neotropics and an important part of its hydrological cycle. An investigation on how elevation and recovery from agriculture affects cloud forest floristics and physical structure in Ecuador was undertaken.

Methods: Species and diameter at a specified height (dsh) of trees were sampled in large plots in Maquipucuna and Yanacocha cloud forests in Ecuador and also in smaller plots at Maquipucuna recovering after cropping in sugarcane (Saccharum officinarum L.) and banana (Musa sp.).

Results: (1) Palicourea sp. was the only species found at both primary sites; Vernonia pallens Sch.Bip., Erythrina megistophylla Diels, Nectandra sp., and Miconia sp. were found in both primary and secondary plots at Maquipucuna; and Miconia sp. was the only species in common between the Maquipucuna secondary plots and the primary plot at Yanacocha Reserve. (2) The mean stem size was similar between the primary Maquipucuna plots and the Yanacocha plot, but the Yanacocha plot had more total stems and more stems in each size category, which lead to more basal area, above-ground biomass, and canopy closure at Yanacocha compared to Maquipucuna. (3) In the secondary plots, there were no stems larger than $29 \mathrm{~cm}$ dsh at breast height, which lead to a much smaller mean stem size and lower basal area, above-ground biomass, and canopy closure compared to the primary plots at both sites.

Conclusions: For the primary cloud forest at Maquipucuna, an increase in elevation changed the species-level floristics more than conversion to and then abandonment from agriculture; however, while a rise in elevation increased the number of stems, agriculture reduced stem size structure.
\end{abstract}

Keywords: Banana, LTER, Maquipucuna Reserve, Sugarcane, Yanacocha Reserve

\section{Background}

Gradients and disturbances are two of the most important forces that shape plant communities because plants often respond to cues created by or associated with them (Pickett and White 1985; Turner and Dale 1991; Whittaker 1975). Indeed, landscapes can be largely seen as a vegetative mosaic created by these two forces. Common gradients include precipitation, soil nutrients, flooding, elevation, and temperature, and disturbances range from the very severe (e.g., landslides) to the moderately severe (conversion to agriculture) to the least severe (tree fall, selective logging).

Correspondence: myster@okstate.edu; http://www.researchgate. net/profile/Randall_Myster

Biology Department, Oklahoma State University, Oklahoma City, OK 73107, USA large elevational gradient (1300-4000 $\mathrm{m}$ above sea level (a.s.l.); Bushush and Silman 2004) and are important to the biogeochemical cycling of surrounding forests (e.g., the hydrological cycle; Hamilton et al. 2012). They are also subject to a variety of large-scale disturbances such as landslides (Myster 1993), conversion to agriculture (Myster 2004b; Myster 2007a; Myster 2012a), and natural tree fall (Myster 2015a). In these forests as elevation increases, net primary productivity decreases (Girardin et al. 2010), height of the canopy and of emergent trees decreases, number of strata or canopy layers also decreases, plants take on different ecotypes (Myster and Fetcher 2005), and growth forms such as buttresses and climbers give way to various kinds of epiphytes 
(Whitmore 1998). Also as elevation increases, trees become shorter and bryophytes become more common especially where cloud condensation becomes more persistent (Grubb et al. 1963). Exposure to wind-driven fog and rain can also cause trees to take on a bent and gnarled physiognomy, and bamboos can replace palms in the understorey (Kappelle and Brown 2001).

Consequently, cloud forests offer excellent opportunities to examine how gradients (in the form of changes in elevation) and disturbances (in the form of old fields recovering after abandonment from agricultural use) affect forest structure, function, and dynamics, where those effects may actually be due to factors associated with gradients (e.g., temperature, humidity) or conversion to agriculture (e.g., soil changes, past crop). For example, Holder (2004) found, in Guatemala, that fog precipitation was greater in a cloud forest at $2550 \mathrm{~m}$ a.s.l. compared with a cloud forest at $2100 \mathrm{~m}$ a.s.l. Likewise, Veneklaas and van Ek (1990) found an increase in interception in Colombian cloud forests with an increase in elevation ( $2550 \mathrm{~m}$ a.s.l. to $3370 \mathrm{~m}$ a.s.l.) and Weaver (1972) found a trend of decreasing interception with increasing elevation in cloud forest of Puerto Rico, where the elevational range of sites varied from $930 \mathrm{~m}$ a.s.l. to $1015 \mathrm{~m}$ a.s.l. Recovery from agricultural uses is slow for cloud forests, similar to temperate old-field rates with small-seeded tree species arriving first followed by understorey trees (Myster and Pickett 1994). Overall richness and structure may take decades to reach primary cloud forest levels (Myster 2004b).

A field study in Ecuador was implemented to expand on past samplings of Neotropic cloud forests (Myster 2014; Nadkarni et al. 1995; Tanner 1997; Weaver et al. 1986) in order to better understand the floristics and physical structure of primary cloud forests and how the natural variation of elevation and the human treatment of agriculture changed them. Plots were installed and measured as follows: (1) four $2500 \mathrm{~m}^{2}(50 \mathrm{~m} \times 50 \mathrm{~m})$ plots in a primary cloud forest at Maquipucuna Reserve; (2) two $500 \mathrm{~m}^{2}(50 \mathrm{~m} \times 10 \mathrm{~m})$ plots in secondary, regenerating cloud forest at Maquipucuna Reserve 17 years after sugarcane (Saccharum officinarum) or banana (Musa sp.) cultivation, and (3) one $2500 \mathrm{~m}^{2}(50 \mathrm{~m} \times$ $50 \mathrm{~m})$ plot in a primary cloud forest at Yanacocha Reserve. Taxonomic authorities for all species referred to in this paper are available from the Plant List http:// www.theplantlist.org/.

Three major questions were addressed: (1) how does an increase in elevation change the floristics (family, genera, species) and forest physical structure (stem density, mean stem size, four stem size classes, total basal area, above-ground biomass, canopy closure) of cloud forest in the Andean Mountains of Ecuador; (2) how does conversion to agriculture change the floristics (family, genera, species) and forest physical structure (stem density, mean stem size, four stem size classes, total basal area, above-ground biomass, canopy closure) of a cloud forest in the Andean Mountains of Ecuador; and (3) which aspects of cloud forest floristics and physical structure are affected by which of these two forces, and does that suggest how they may interact to produce cloud forests?

\section{Methods}

\section{Study sites and sampling}

(1) Primary cloud forest at Maquipucuna Reserve (MR $0^{\circ} 05^{\prime} \mathrm{N}, 78^{\circ} 37^{\prime} \mathrm{W}$; www.maqui.org; Sarimento 1997; Myster and Sarmiento 1998; Rhoades et al. 1998; Rhoades and Coleman 1999) located $20 \mathrm{~km}$ from the town of Nanegalito, Ecuador. This reserve lies between $1200 \mathrm{~m}$ and $1800 \mathrm{~m}$ a.s.l. and is classified as tropical lower montane wet/cloud forest (Edmisten 1970). It has deeply dissected drainages with steep slopes and has an annual precipitation of $3198 \mathrm{~mm}$ (measured from Nanegal: Sarimento 1997). The temperature ranges yearly between 14 and $25^{\circ} \mathrm{C}$, with an average temperature of $18^{\circ}$ C. The reserve's fertile andisol soil is developed from recent volcanic ash deposits. The reserve is located in the Choco-Andean Corridor which is one of the top five biodiversity hot spots on earth (Sarimento 1995). In May 2012, four $2500 \mathrm{~m}^{2}(50 \mathrm{~m} \times 50 \mathrm{~m})$ plots were selected as representative sites by experienced local field assistants, suggested by local field assistants, within MR primary cloud forest at $1400 \mathrm{~m}$ a.s.l. We then tagged and measured the diameter at a specific height (dsh) of all trees at least $10 \mathrm{~cm}$ dsh in each of the $2510 \mathrm{~m} \times 10 \mathrm{~m}$ contiguous subplots that make up each $2500 \mathrm{~m}^{2}$ plot. The dsh measurement was taken at the nearest lower point where the stem was cylindrical, and for buttressed trees, it was taken above the buttresses. The tagged trees were also identified to species or to genus only when species identification was not possible.

(2) Within MR are secondary cloud forests of recovering sugarcane plantations, banana plantations, and pastures seeded with the grass Setaria sphacelata which is native to Africa (Myster 2014; Sarimento 1997; Zahawir and Augspurger 1999). In June 1996, $500 \mathrm{~m}^{2}(50 \mathrm{~m} \times 10 \mathrm{~m})$ plots were laid out in just abandoned sugarcane plantation and in just abandoned banana plantation selected as representative sites by experienced local field assistants. In May 2011, each plot was measured using the same proto$\mathrm{col}$ as in (1). These plots are part of the longest and largest old-field study in the Neotropics (Myster 2004a; Myster 2004b; Myster 2007a; Myster 2007b; Myster 2009; Myster 2010a, 2010b; Myster 2014) funded by the US National Science Foundation (see Myster 2012a for details). The plots are located within a few hundred meters of each other at the lower elevations of MR (1200 m a.s.l.). 
(3) Primary cloud forest at Yanacocha Reserve (YR: http://fjocotoco.org/reserves-yanacocha) managed by Fundacion Jocotoco and supported by a World Land Trust land purchase and Carbon Balanced funding is located on the northeastern slope of the Pichincha Volcano about $45 \mathrm{~min}$ northwest of Quito along the old Nono-Mindo Road on route to the Mindo Valley. The reserve was established in 2001 to protect the blackbreasted Puffleg (Eriocnemis nigrivestis) whose known range is restricted to the Pichincha Volcano. The YR is mainly high-elevation elfin Polylepis sp. forest. In May 2015 , one $2500 \mathrm{~m}^{2}(50 \mathrm{~m} \times 50 \mathrm{~m})$ plot was established in YR primary cloud forest at $3400 \mathrm{~m}$ a.s.l., in a random location suggested by local field assistants, and measured using the exact protocol as in (1).

\section{Species identification}

Voucher specimens are kept on file at the University of Georgia, USA. Plant taxonomists at the University assisted in the identification of species using Romoleroux et al. (1997) and Gentry (1993) as taxonomic sources. They also consulted the web site of the Missouri Botanical Garden (www.mobot.org).

\section{Data analysis}

Data collected from all plots were used to compile floristic tables of family, genus, and species. Also calculated were: (1) the total number of stems, the mean dsh among those stems, and the total number of stems divided into four size classes: $10<20 \mathrm{~cm}$ dsh, $20<30 \mathrm{~cm}$ $\mathrm{dsh}, 30<40 \mathrm{~cm}$ dsh, and $\geq 40 \mathrm{~cm}$ dsh; (2) total basal area as the sum of the basal areas of all individual stems $\left(\pi r^{2}\right.$; where $r=$ the dsh of the individual stem/2); (3) above-ground biomass (AGB) using the formula in Nascimento and Laurance (2001) and suggested for tropical trees of these stem sizes; and (4) canopy closure using the formula in Buchholz et al. (2004) for tropical trees.

\section{Results}

There were a total of 25 families found among all seven plots (Table 1). Chloranthaceae, Lauraceae, and Melastomataceae were the most abundant families. Actinidaceae and Melastomataceae were the only families found in all five 0.25-ha plots, but there were no families found in all seven plots (Table 1). The most abundant species in the primary cloud forest plots at MR were Erythrina megistophylla and Nectandra acutifolia (Table 2), and in the primary cloud forest plot at YR, Hedyosman canatreecasunam and Miconia sp. were the most abundant (Table 3). Palicourea sp. was the only species found at both primary cloud forest sites with members of the genera Saurania and Miconia also found at both sites (Tables 2 and 3).
Table 1 Details of each family that occurred in all seven plots (and their frequency) sorted in alphabetical order with the total number of stems found: in primary cloud forest at Maquipucuna Reserve (MR1), (MR2), (MR3), and (MR4); in primary cloud forest at Yanacocha Reserve (YA); and in secondary cloud forest at Maquipucuna Reserve

\begin{tabular}{|c|c|c|c|c|c|c|c|}
\hline Family & MR1 & MR2 & MR3 & MR4 & YA & $\mathrm{S}$ & $B$ \\
\hline Actinidaceae & 8 & 4 & 6 & 6 & 1 & 0 & 0 \\
\hline Araliaceae & 0 & 0 & 0 & 0 & 1 & 0 & 0 \\
\hline Asteraceae & 0 & 1 & 0 & 0 & 14 & 3 & 1 \\
\hline Boraginaceae & 0 & 0 & 0 & 0 & 5 & 0 & 0 \\
\hline Bromeliaceae & 1 & 0 & 0 & 0 & 0 & 0 & 0 \\
\hline Cecropiaceae & 0 & 0 & 3 & 4 & 0 & 1 & 0 \\
\hline Chloranthaceae & 0 & 0 & 0 & 0 & 77 & 2 & 1 \\
\hline Cunoniaceae & 0 & 0 & 0 & 0 & 10 & 0 & 0 \\
\hline Cyatheacaeae & 0 & 0 & 0 & 0 & 1 & 0 & 0 \\
\hline Euphorbiaceae & 0 & 0 & 0 & 0 & 0 & 2 & 0 \\
\hline Fabaceae & 12 & 5 & 15 & 17 & 0 & 0 & 2 \\
\hline Lamiaceae & 0 & 0 & 0 & 0 & 1 & 0 & 0 \\
\hline Lauraceae & 28 & 35 & 37 & 18 & 0 & 2 & 2 \\
\hline Melastomataceae & 1 & 1 & 6 & 2 & 86 & 0 & 3 \\
\hline Mimosaceae & 3 & 3 & 0 & 1 & 0 & 0 & 0 \\
\hline Monimiaceae & 0 & 0 & 0 & 1 & 0 & 0 & 0 \\
\hline Moraceae & 0 & 2 & 0 & 0 & 0 & 0 & 0 \\
\hline Myristicaceae & 3 & 2 & 4 & 0 & 0 & 0 & 0 \\
\hline Myricaceae & 0 & 0 & 0 & 0 & 3 & 0 & 0 \\
\hline Myrtaceae & 0 & 1 & 1 & 2 & 0 & 0 & 0 \\
\hline Piperaceae & 2 & 0 & 2 & 1 & 0 & 4 & 0 \\
\hline Rubiaceae & 5 & 0 & 3 & 3 & 24 & 0 & 0 \\
\hline Solanaceae & 0 & 1 & 1 & 3 & 0 & 0 & 1 \\
\hline Tiliaceae & 0 & 0 & 1 & 1 & 0 & 0 & 0 \\
\hline Urticaceae & 4 & 3 & 5 & 0 & 0 & 1 & 0 \\
\hline Verbenaceae & 8 & 4 & 8 & 4 & 0 & 0 & 0 \\
\hline
\end{tabular}

$S$ recovering sugarcane field, $B$ recovering banana field

The most abundant species in the secondary cloud forest plots at MR were Vernonia pallens, Nectandra sp., and Piper aduncum (Table 4). Piper aduncum was the most abundant species in the recovering sugarcane plot, and Miconia sp. was the most abundant species in the recovering banana plot (Table 4). Vernonia pallens, Erythrina megistophylla, Nectandra sp., and Miconia sp. were found in both primary and secondary plots at MR as was the genera Cecropia and Piper (Tables 2 and 4). Miconia sp. was the only species in common between the MR secondary plots and the primary cloud forest plot at YR, but the genus Hedyosmum was present at both sites (Tables 3 and 4).

Although the mean stem size was similar between the primary MR plots and the YR plot (Table 5), the YR plot 
Table 2 All species $\geq 10 \mathrm{~cm}$ dsh sampled in the four $50 \mathrm{~m} \times 50 \mathrm{~m}$ plots in primary cloud forest at Maquipucuna Reserve (MR1, MR2, MR3, MR4) with their number of stems

\begin{tabular}{|c|c|c|c|c|c|c|c|}
\hline Family & Genus & Species & MR1 & MR2 & MR3 & MR4 & Mean \\
\hline Actinidaceae & Saurauia & priannana & 1 & 2 & 0 & 1 & 1.0 \\
\hline Asteraceae & Vernonia & patens & 0 & 0 & 0 & 1 & 0.25 \\
\hline Bromeliaceae & Bromelia & sp. & 1 & 0 & 0 & 1 & 0.50 \\
\hline Cecropiaceae & Cecropia & sp. & 2 & 2 & 3 & 0 & 1.75 \\
\hline Fabaceae & Erythrina & megistophylla & 15 & 11 & 16 & 7 & 12.25 \\
\hline Lauraceae & Nectandra & acutifolia & 25 & 34 & 29 & 30 & 29.50 \\
\hline Lauraceae & Nectandra & sp. & 0 & 1 & 0 & 0 & 0.25 \\
\hline Melastomataceae & Meriania & maxima & 0 & 1 & 0 & 0 & 0.25 \\
\hline Melastomataceae & Miconia & sp. & 2 & 2 & 5 & 1 & 2.50 \\
\hline Mimosaceae & Inga & sp. & 0 & 4 & 3 & 0 & 1.75 \\
\hline Monimiaceae & Siparuna & aspera & 0 & 0 & 1 & 0 & 0.25 \\
\hline Moraceae & Ficus & sp. & 0 & 0 & 0 & 1 & 0.25 \\
\hline Myristicaceae & Otoba & gordoniifolia & 4 & 3 & 2 & 1 & 2.50 \\
\hline Myrtaceae & Eugenia & sp. & 2 & 0 & 0 & 3 & 1.25 \\
\hline Piperaceae & Piper & sp. & 1 & 1 & 1 & 2 & 1.25 \\
\hline Rubiaceae & Faramea & flavicans & 1 & 0 & 0 & 1 & 0.50 \\
\hline Rubiaceae & Ladenbergia & sp. & 0 & 0 & 2 & 1 & 0.75 \\
\hline Rubiaceae & Policourea & sp. & 2 & 5 & 4 & 0 & 2.75 \\
\hline Rutaceae & Zanthoxylum & sp. & 0 & 0 & 0 & 2 & 0.50 \\
\hline Solaneceae & Cestrum & sp. & 2 & 0 & 2 & 1 & 1.25 \\
\hline Tiliaceae & Triunfeta & sp. & 0 & 1 & 0 & 1 & 0.50 \\
\hline Urticaceae & Urera & sp. & 5 & 3 & 2 & 2 & 3.00 \\
\hline Verbenaceae & Aegiphila & sp. & 6 & 8 & 3 & 7 & 6.00 \\
\hline
\end{tabular}

Table 3 All species $\geq 10 \mathrm{~cm}$ dsh sampled in the $50 \mathrm{~m} \times 50 \mathrm{~m}$ plot in primary cloud forest at Yanacocha Reserve with number of stems

\begin{tabular}{llll}
\hline Family & Genus & Species & YA \\
\hline Actinidiaceae & Saurauia & cf tomentosa & 1 \\
Araliaceae & Schefflera & sp. & 1 \\
Asteraceae & Senecio & sp. & 14 \\
Boraginaceae & Tournefortia & sp. & 5 \\
Chloranthaceae & Hedyosman & cauatrecasanum & 77 \\
Cunoniaceae & Weinmannia & cf fagaroides & 10 \\
Cyatheacaea & Cyathea & sp. & 1 \\
Lamiaceae & Aegiphyla & sp. & 1 \\
Melastomataceae & Blakea & sp. & 15 \\
Melastomataceae & Miconia & sp. & 71 \\
Myricaceae $_{\text {Rubiaceae }}^{\text {a }}$ & Morella & cerifera & 3 \\
Rubiaceae $^{\text {a }}$ & Palicourea & sp. & 4
\end{tabular}

${ }^{\mathrm{a} S p e c i e s ~ a l s o ~ f o u n d ~ i n ~ p r i m a r y ~ c l o u d ~ f o r e s t ~ p l o t s ~ a t ~ M a q u i p u c u n a ~}$
Table 4 All species $\geq 10 \mathrm{~cm}$ dsh sampled in the $50 \mathrm{~m} \times 10 \mathrm{~m}$ plots in secondary cloud forest at Maquipucuna Reserve with their number of stems

\begin{tabular}{lllll}
\hline Family & Genus & Species & S & B \\
\hline Asteraceae & Vernonia & pallens & 3 & 1 \\
Cecropiacea & Cecropia & monostachyma & 1 & 0 \\
Chloranthaceae & Hedyosmum & sp. & 2 & 1 \\
Euphorbiaceae & Acalypha & platyphylla & 1 & 0 \\
Euphorbiaceae & Croton & eluterin & 1 & 0 \\
Fabaceae $^{\text {a }}$ & Erythrina & megistophylla & 0 & 1 \\
Fabaceae $_{\text {Lauraceae }}^{\text {a }}$ & Inga & sp. & 0 & 1 \\
Melastomataceae $^{\text {a }}$ & Nectandra & sp. & 2 & 2 \\
Piperaceae $_{\text {Solanaceae }}$ & Piper & sp. & 0 & 3 \\
Urticaceae $^{\text {Sila }}$ & Solanum & sp. & 4 & 0 \\
\hline
\end{tabular}

$S$ recovering sugarcane field, $B$ recovering banana field ${ }^{\text {a }}$ Species also found in primary cloud forest plots at Maquipucuna 
Table 5 Physical structure parameters for all trees $\geq 10 \mathrm{~cm}$ dsh sampled in the four $2500 \mathrm{~m}^{2}$ plots, primary cloud forest Maquipucuna Reserve (MR1, MR2, MR3, MR4) in May 2012, and in the one $2500 \mathrm{~m}^{2}$ plot, primary cloud forest Yanacocha Reserve (YR) in May 2015

\begin{tabular}{llllll}
\hline Parameter & MR1 & MR2 & MR3 & MR4 & YR \\
\hline Stem density & 68 & 70 & 81 & 75 & 193 \\
$\quad$ Total & 45 & 39 & 38 & 31 & 91 \\
$\quad 10<19 \mathrm{~cm}$ dsh & 24 & 21 & 18 & 19 & 56 \\
$\quad 20<29 \mathrm{~cm}$ dsh & 14 & 9 & 11 & 12 & 24 \\
$\quad 30<39 \mathrm{~cm}$ dsh & 3 & 3 & 5 & 2 & 22 \\
$\quad 40$ cm or greater & 22.0 & 22.1 & 23.8 & 22.8 & 23.1 \\
$\quad$ Mean dsh (cm) & 11 & 12 & 13 & 13 & 11 \\
Family richness & 14 & 13 & 13 & 17 & 13 \\
Genus richness & 14 & 14 & 13 & 17 & 13 \\
Species richness & 2.2 & 3.2 & 2.4 & 3.2 & 5.2 \\
Basal area (m ${ }^{2}$ ) & 49.0 & 49.7 & 48.3 & 51.4 & 87.2 \\
Above-ground biomass (Mg) & 45.2 & 45.9 & 46.2 & 47.7 & 65.2 \\
Canopy closure (\%) & & & &
\end{tabular}

had more total stems and more stems in each size category which lead to more basal area, AGB, and canopy closure at YR. All five plots had a reverse J stem size distribution pattern. Richness of families, genera, and species were slightly less in the YR plot compared to the MR primary plots (Table 5).

At MR, the secondary cloud forest plots are one quarter the size of each of the primary cloud forest plots. When adjusting for these differences in area by multiplying by four, the total number of stems and the number of stems in the first two size classes were slightly smaller than any of the primary cloud forest plots. But the largest difference was that there were no stems larger than $29 \mathrm{~cm}$ dsh in either the sugarcane or the banana plot (Table 6), which led to a much smaller mean stem size in the secondary plots. Richness of families, genera, and species were all less here when compared to both the MR plots and the YR plot but similar between past crops (sugarcane vs. banana). Given the smaller number of stems and stem size, the basal area, AGB, and canopy coverage were much lower in the sugarcane and banana fields compared to the primary plots at MR and YR (Table 6).

\section{Discussion}

There were several more species in common between the primary Maquipucuna cloud forest and the secondary Maquipucuna cloud forest than between the primary Maquipucuna cloud forest and the primary Yanacocha cloud forest. This suggests that cloud forest floristics is affected more by an increase in elevation (here $2000 \mathrm{~m}$ ) than by past sugarcane and banana cultivation (here 17 years after abandonment). In terms of forest physical
Table 6 Physical structure parameters for all trees $\geq 10 \mathrm{~cm}$ dsh sampled in the four $2500 \mathrm{~m}^{2}$ plots and in sugarcane fields $\left(\mathrm{S}: 500 \mathrm{~m}^{2}\right)$ and in banana fields $\left(\mathrm{B}: 500 \mathrm{~m}^{2}\right)$. All plots are located at Maquipucuna Reserve

\begin{tabular}{lllllll}
\hline Parameter & MR1 & MR2 & MR3 & MR4 & S & B \\
\hline Stem density & & & & & & \\
$\quad$ Total & 68 & 70 & 81 & 75 & 15 & 10 \\
$\quad 10<19 \mathrm{~cm}$ dsh & 45 & 39 & 38 & 31 & 11 & 7 \\
$\quad 20<29 \mathrm{~cm}$ dsh & 24 & 21 & 18 & 19 & 4 & 3 \\
$\quad 30<39 \mathrm{~cm}$ dsh & 14 & 9 & 11 & 12 & 0 & 0 \\
$\quad 30 \mathrm{~cm}$ or greater & 3 & 3 & 5 & 2 & 0 & 0 \\
$\quad$ Mean dsh (cm) & 22.0 & 22.1 & 23.8 & 22.8 & 5.6 & 4.6 \\
Family richness & 11 & 12 & 13 & 13 & 7 & 6 \\
Genus richness & 14 & 13 & 13 & 17 & 8 & 7 \\
Species richness & 14 & 14 & 13 & 17 & 8 & 7 \\
Basal area (m ${ }^{2}$ ) & 2.2 & 3.2 & 2.4 & 3.2 & 0.76 & 0.69 \\
Above-ground biomass (Mg) & 49.0 & 49.7 & 48.3 & 51.4 & 14.87 & 15.24 \\
Canopy closure (\%) & 45.2 & 45.9 & 46.2 & 47.7 & 11.22 & 8.95 \\
\hline
\end{tabular}

structure, with an increase in elevation, there is a gain in tree stems of all sizes but a loss of some diversity, especially at the species level. This leads to a more closed and structurally (but not floristically) complex cloud forest at the higher elevations. Large trees are absent in the recovering sugarcane and banana plots, which produces large differences in physical structure, and thus, the secondary forest at MR may reach floristic similarity before structural similarity.

Comparing the two study primary cloud forests to the primary cloud forest at Monteverde, Costa Rica, also sampled for all trees at least $10 \mathrm{~cm}$ dsh, there was a similar number of stems (555/ha) but more basal area $\left(62 \mathrm{~m}^{2} /\right.$ ha: Nadkarni et al. 1995) but the same reverse J size distribution. There were many families in common: Asteraceae, Cecropiacea, Fabaceae, Lauraceae, Melastomataceae, Moraceae, Myristicacea, Myrtaceae, Myrtaceae, Piperaceae, Rubiaceae, Solanaceae, Tiliaceae, Urticaceae, and Verbenaceae, but only Fabaceae and Lauraceae were abundant. Cecropia was the only genus in common as well.

The stem density for all trees at least $10 \mathrm{~cm}$ dsh in another primary cloud forest sampling in Costa Rica was comparable to YR (553/ha: Heaney and Protor 1990), but low in Jamaica (Tanner 1997) and Ecuador (Grubb et al. 1963), which puts the MR sampling somewhere in between. In Puerto Rican "dwarf" cloud forest, there were many small stems (3671/ha) but the basal area was comparable to Monteverde in Costa Rica $\left(49.1 \mathrm{~m}^{2} / \mathrm{ha}\right.$ : Weaver et al. 1986). In cloud forests closer to Ecuador (Venezuela) sampled to a dsh of at least $10 \mathrm{~cm}$, the stem density (365-850/ha) and species richness (9-14/ha) was also comparable (Schwarzkopf et al. 2011). 
Previous studies of the sugarcane and banana plots have compared floristics and physical structure like in this study (Myster 2007a); for example, relationships between richness and productivity (Myster 2009) and dominance-diversity curves (Myster 2010a, 2010b). These studies have also included field experiments into regeneration mechanisms and tolerances at MR (Myster 2004a; Myster 2015a) and have shown that seed predators took most of the seed and had their greatest effect in closed-canopy primary cloud forest, a medium effect in tree-fall gaps in primary cloud forest, and least effect in secondary cloud forest (Myster 2015a).

Field experiments into how elevation affects seed processes were also done at Guandera biological station also in Ecuador (also at $3400 \mathrm{~m}$ a.s.l.) and at MR (Randall Myster: unpub. data). In that study, I found: (1) the two study sites were significantly different for all three seed processes but where seed predation dominated Maquipucuna, seed pathogens dominated Guandera; (2) closedcanopy vs. tree-fall gap variation was only significant for germination; (3) species were significantly different for both seed predation (Solanum stenophyllum [11\%], Palicourea amethystine [16\%], Clusia flaviflora [13\%] Engl., Cecropia sp. [79\%], Ardisia websteri [83\%], Prestoea acuminate [84\%], Ficus sp. [85\%], Otoba gordoniifolia [69\%]) and for seed pathogens (Solanum stenophyllum [43\%], Palicourea amethystine [52\%], Clusia flaviflora [68\%] Engl., Cecropia sp. [14\%], Ardisia websteri [7\%], Prestoea acuminate [4\%], Ficus sp. [4\%], Otoba gordoniifolia [7\%]); and (4) there were significant interaction terms for elevation $\times$ species seed predation, where it was driven by the differences between study sites and the tree seed species Palicourea amethystine, and for elevation $\times$ species seed pathogens, where it was driven by the differences between study sites and the tree seed species Otoba gordoniifolia. Thus, cloud forest recruitment and regeneration is affected less by predation and more by pathogens, as elevation increases.

\section{Conclusions}

In conclusion, (1) elevation affects both floristics and physical structure in these Andean cloud forests and I continue my work at other high-altitude sites in order to examine these differences in more detail and, (2) after 17 years while the old fields have species in common with the primary MR forest, they are not floristically similar and differences suggest that there may continue to be a lingering effect of the past crops of sugarcane vs. banana (a crop signature: Myster 2004b). Structural differences are consistent with trends in successional vs. primary vegetation studies elsewhere (see chapters in Myster 2007b). These permanent plot studies, and others like them, provide baseline data on forest dynamics (i.e., plant-plant replacements: Myster 2012c) and fluctuations of forest structure.

\section{Acknowledgements}

I thank Arcenio Barras, Bernardo Castro, Jorge Reascos, Rebeca Justicia, and the staff of Maquipucuna Reserve for their help in executing this research. I also thank E. Bruna, D. Bonte, A. Chiarucci, P. Campanello, P. Bernier, and A. Austin for commenting on a previous draft of the manuscript.

\section{Competing interests}

The author declares that he has no competing interests.

Received: 27 June 2016 Accepted: 23 December 2016

Published online: 20 January 2017

\section{References}

Buchholz, T., Tennigkeit, T., \& Weinreich, A. (2004). Maesopsis eminii-a challenging timber tree species in Uganda-a production model for commercial forestry and smallholders. Proceedings of the international union of forestry research organizations (IUFRO) conference on the economics and management of high productivity plantations, Lugo, Spain.

Bushush, M. B., \& Silman, M. R. (2004). 48,000 years of climate and forest change in a biodiversity hot spot. Science, 303, 827-829.

Edmisten, J. (1970). Some autoecological studies of Ormosia krugii. In H. T. Odum \& R. F. Pigeon (Eds.), A tropical rain forest. Springfield: National Technical Information Service. Chapter D-8.

Gentry, A. A. (1993). Field guide to woody plants of northwest South America (Colombia, Ecuador, Peru). Washington, DC: Conservation International.

Girardin, C. Y., Malhi, L., Aragao, M., Mamani, W., Huaraaca-Huaraca, W., \& Durand, L. (2010). Net primary productivity allocation and cycling of carbon along a tropical forest elevational transect in the Peruvian Andes. Global Change Biology, 16, 3176-3192

Grubb, P. J., Lloyd, J. R., Pennington, T. D. A., \& Whitmore, T. C. A. (1963). Comparison of montane and lowland rain forest in Ecuador. I. The forest structure, physiognomy, and floristics. Journal of Ecology, 51, 567-601.

Hamilton, L. S., Juvik, J. O., \& Scatena, F. N. (2012). Tropical montane cloud forests. Berlin: Springer-Verlag.

Heaney, A., \& Protor, J. (1990). Preliminary studies on forest structure and floristics on Volcan Barva Costa Rica. Journal of Tropical Ecology, 6, 307-320.

Holder, C. D. (2004). Rainfall interception and fog precipitation in a tropical montane cloud forest of Guatemala. Forest Ecology and Management, 190, 373-384.

Kappelle, M., \& Brown, A. D. (2001). Bosques nublados del Neotropico. Heredia, Costa Rica: Instituto Nacional de Biodiversidad.

Myster, R. W. (1993). Spatial heterogeneity of seed rain, seed pool, and vegetative cover on two Monteverde landslides, Costa Rica. Brenesia, 39-40, 137-145.

Myster, R. W. (2004a). Regeneration filters in post-agricultural fields of Puerto Rico and Ecuador. Plant Ecology, 172, 199-209.

Myster, R. W. (2004b). Post-agricultural invasion, establishment and growth of neotropical trees. The Botanical Review, 70, 381-402.

Myster, R. W. (2007a). Early successional pattern and process after sugarcane, banana and pasture cultivation in Ecuador. New Zealand Journal of Botany, 46, 101-110.

Myster, R. W. (2007b). Post-agricultural succession in the neotropics. Berlin: Springer

Myster, R. W. (2009). Are productivity and richness related consistently after different crops in the neotropics? Botany, 87, 1-6.

Myster, R. W. (2010a). Testing dominance-diversity hypotheses using data from abandoned plantations and pastures in Puerto Rico and Ecuador. Journal of Tropical Ecology, 26, 247-250.

Myster, R. W. (2010b). Flooding gradient and treefall gap interactive effects on plant community structure, richness, and alpha diversity in the Peruvian Amazon. Ecotropica, 16, 43-49.

Myster, RW. (2012a). Long-term data from fields recovering after sugarcane, banana and pasture cultivation in Ecuador. Dataset papers in Ecology Volume 2013, Article ID - 468973.10 pages, DOI 10.7167/2013/46873.

Myster, R. W. (2012a). Post-agricultural ecotones in Puerto Rico. In R. W. Myster (Ed.), Ecotones-between forest and grassland (pp. 147-166). Berlin: Springer-Verlag.

Myster, R. W. (2012b). Plants replacing plants: the future of community modeling and research. The Botanical Review, 78, 2-9. 
Myster, R. W. (2014). Primary vs. secondary forests in the Neotropics: two case studies after agriculture. Pp 1-42 in forest ecosystems: biodiversity, management and conservation. NY: Nova publishers.

Myster, R. W. (2015). Seed predation, pathogens and germination in primary vs. secondary cloud forest at Maquipucuna Reserve, Ecuador. Journal of Tropical Ecology, 31, 375-378.

Myster, R. W., \& Fetcher, N. (2005). Ecotypic differentiation and plant growth in the Luquillo Mountains of Puerto Rico. Journal of Tropical Forest Science, 17, 163-169.

Myster, R. W., \& Pickett, S. T. A. (1994). A comparison of rate of succession over $18 \mathrm{yr}$ in 10 contrasting old fields. Ecology, 75, 387-392.

Myster, R. W., \& Sarmiento, F. O. (1998). Seed inputs to microsite patch recovery on tropandean landslides in Ecuador. Restoration Ecology, 6, 35-43.

Nadkarni, N. M., Matelson, T. J., \& Haber, W. A. (1995). Structural characteristics and floristic composition of a neotropical cloud forest, Monteverde, Costa Rica. Journal of Tropical-Ecology, 4, 481-495.

Nascimento, H. E. M., \& Laurance, W. F. (2001). Total aboveground biomass in central Amazonian rainforests: a landscape-scale study. Forest Ecology and Management, 157, 1-11

Pickett, S. T. A., \& White, P. S. (1985). The ecology of natural disturbance and patch dynamics. NY: Academic Press.

Rhoades, C. C., \& Coleman, D. C. (1999). Nitrogen mineralization and nitrification following land conversion in montane Ecuador. Soil Biology and Biochemistry, $31,1347-1354$

Rhoades, C. C., Eckert, G. E., \& Coleman, D. C. (1998). Effect of pasture trees on soil nitrogen and organic matter: implications for tropical montane forest restoration. Restoration Ecology, 6, 262-270.

Romoleroux, K., Foster, R., Valencia, R., Condit, R., Balslev, H., \& Losos, E. (1997). Especies Lenosas (dap $\Rightarrow>1 \mathrm{~cm}$ ) encontradas en dos hectareas de un bosque de la Amazonia ecuatoriana. In R. Valencia \& H. R. Balslev (Eds.), Estudios Sobre Diversidad y Ecologia de Plantas (pp. 189-215). Quito, Ecuador: Pontificia Universidad Catolica del Ecuador.

Sarimento, F. O. (1995). Naming and knowing a tropandean landscape: the Maquipucuna Reserve as a case study. The George Wright Forum, 12, 15-22.

Sarimento, F. O. (1997). Arrested succession in pastures hinders regeneration of tropandean forests and shreds mountain landscapes. Environmental Conservation, 24, 14-23.

Schwarzkopf, T., Riha, S. J., Fahey, T. J., \& Degloria, S. (2011). Are cloud forest tree structure and environment related in the Venezuelan Andes? Austral Ecology, 36, 280-289

Tanner, E. V. J. (1997). Four montane rain forests of Jamaica: a quantitative characterization of the floristics, the soils and the foliar mineral levels, and a discussion of the interrelations. Journal of Ecology, 65, 883-918.

Turner, M. G., \& Dale, V. H. (1991). Modeling landscape disturbance. In M. G. Turner \& R. H. Gardner (Eds.), Quantitative methods in landscape ecology (pp. 323-351). Berlin: Springer-Verlag.

Veneklaas, E. J., \& van Ek, R. (1990). Rainfall interception in two tropical montane rain forests, Colombia. Hydrological process, 4, 311-326.

Weaver, P. L. (1972). Cloud moisture interception in the Luquillo Mountains of Puerto Rico. Caribbean Journal of Science, 12, 129-144.

Weaver, P. L., Medina, E., Pool, D., Dugger, K., Gonzales-Liboy, J., \& Cuevas, E. (1986). Ecological observations in the dwarf cloud forest of the Luquillo Mountains in Puerto Rico. Biotropica, 18, 79-85.

Whitmore, T. C. (1998). An introduction to tropical rain forests. Oxford: Clarendon Press. Whittaker, R. H. (1975). Communities and ecosystems. NY: MacMillian.

Zahawir, R. A., \& Augspurger, C. K. (1999). Early plant succession in abandoned pastures in Ecuador. Biotropica, 31, 123-129.

\section{Submit your manuscript to a SpringerOpen ${ }^{\circ}$ journal and benefit from:}

- Convenient online submission

- Rigorous peer review

- Immediate publication on acceptance

Open access: articles freely available online

- High visibility within the field

- Retaining the copyright to your article

Submit your next manuscript at $>$ springeropen.com 